\title{
Measuring Intellectual Capital Efficiency Based on the Use of Human Resource Accounting
}

\author{
1Mohammad Ahmadi \\ 2Hosseinali Lashkari \\ ${ }^{3}$ Rashid Arghan \\ ${ }^{1}$ Master of Accounting, Electricity Distribution Company of Semnan Province \\ ${ }^{2}$ Financial Expert, Electricity Distribution Company of Semnan Province \\ 3Management Expert, Electricity Distribution Company of Semnan Province
}

Doi:10.5901/mjss.2016.v7n5s1p178

\begin{abstract}
Today, the growing importance of intellectual capital can be recognized by widely use of terms such as intellectual property, scientific capital, scientific organizations, educational organizations, information age and intellectual management. Regardless of capital, technology, equipment, and raw materials, what distinguishes organizations from each other is skilled and efficient human resource, which undoubtedly can be the most important factor in the success or failure of organizations. Therefore, skilled human resources are important for an organization just like its physical assets and investments. On the other hand, modern accounting is accounting of intangible products and assets that are made by these products are mainly intangible assets. What provides the information required to assess human resource criteria, defines human resource functions in achieving the organizational goals, and thereby causes productivity and improvement in the organization is human resource accounting. In this paper, first we provide an overview of knowledge management and intellectual capital, then we evaluate the need for human resource accounting for the efficiency of the organization's intangible assets, as well as measurement methods and models. Finally, some recommendations will be made for the better use of the talent within the organization and the maximum use of the human resources accounting.
\end{abstract}

Keywords: Intellectual capital, human resources, human resources accounting, human resources accounting reporting, costing and valuation.

\section{Introduction}

The mission of contemporary man and contemporary society against the future is to recognize changes using wisdom and direct these changes and their acceleration with sound and measured judgment to balance and order both blind acceptance of resistance to change would be inappropriate and even dangerous, and it is obvious that in the way of achieving the goals of the organization, managers need talented young people as they need valuable experience of old employees for the survival of the system and their organization. Basically, through different mindset, young staff have different expectations compared to older generations of employees, and this is a fundamental point that managers should have special attention to. Most young people have different ideas now. They believe that they have to work few years and then take this experience into a better place (This is not said to their managers), and if managers do not closely consider this fact and do not provide ground for talents in the organization, they will lose them. Managers need to know what kind of talent they have in their organization, and what kind of talents are important according to their organization's mission and strategy.

In the current complex and developmental business environment, survival of organizations depends on introducing new products, creating innovation, and delivering increased value processes based on modern science. In new discussions, the human resource and its assessment strategies is particularly important, so that it is an eternal resource, on the other hand, less attention to it will affect all other sources. Milton Friedman believes that total wealth includes a variety of income sources and services, and human resources is one of the sources of income. To enhance the efficiency of the organization, managers always spent huge sums on training their employees. In addition, in the current era, organizations are able to determine to what extent they can gain profit using intellectual capital of people at their disposal, and the most important tools available to organizations to achieve this objective and accurate determination of the value 
of services provided by human resources in the organization is human resource accounting system. The most essential goal of human resource accounting is to quantify the economic value of individuals for organizations to provide useful information for financial and management decision-making.

\section{Literature Review}

Intellectual Capital is highly regarded, but rarely defined. The most important definitions are as follows:

a. Intellectual capital is a concept that encompasses all the intangible resources and the interactions between them.

b. Intellectual capital including knowledge-based assets is differentiated from both physical and virtual infrastructure and role players.

c. Scandia defines intellectual capital as a set of knowledge, applied experience, organizational technology, customer relationships, and professional skills which brings competitive advantage to Scandia.

As a result, measurement of intellectual capital is important for two reasons: first, internal aspect with the goal of the most efficient dedication of resources while minimizing the costs. Second, external reason with the aim of providing access to data related to existing and potential investment of the organization to predict future growth and provide long term planning. The most important tool available to organizations to achieve these goals as well as to determine the exact value of the services provided by the organization's intangible assets is human resources accounting system.

Since the birth of modern accounting, accountants have passed inventory reporting, financial, and management steps, and the future challenge of accounting is its fourth step or "socio-economic accounting", that includes human resource accounting.

According to the definition of the American Accounting Association (AAA), human resources accounting is: "the process of detecting and measuring information on human resources and reporting this information to interested persons and stakeholders".

The Human Resource Accounting Committee of the American Society also defines it as "sequence of steps to helps identify and supply the required data related to human resources and disseminates this information to the stakeholders".

\section{The Necessity to Measure Intellectual Capital}

The necessity to measure intellectual capital is examined and human resources accounting should be quantified in order to achieve the following objectives:

a. Taking into account the economic value of investments recorded in the financial statements of an organization and how best strategy is to set.

b. Increase the efficiency of human resource management in line with the implementation of organizational strategies are done.

With better human resource assessment can be developed and achieved diversity in the organization. Using the above evaluation results can be better wage and salary compensation system design, and the identification of Non-profit and productivity caused by this investment can be calculated.

By notifying the measure of human resources to stakeholders outside the organization can help them in decision making and investment.

\section{Intellectual Capital Measurement Models}

Most description models proposed to measure intellectual capital can be divided into four categories: direct intellectual capital models, models based on market capital, return on assets models, and balanced card models.

\subsection{Direct intellectual capital models}

This model calculates monetary value of intellectual capital by identifying its various components. Models associated with this style include:

1. Human resource accounting model that is based on quantifying the economic value of the organization in order to provide data for financial management decision making.

2. Human resources financial statement based on workload that works depending on the number of employees, 
activities conducted based on characteristics of the individuals, and organizational cooperation.

3. Technology broker model that is based on four components including market assets, human-centered assets, intellectual property assets, and infrastructural assets.

4. Intellectual property valuation model that is based on the idea that human capital and intellectual property are effective in the formation of intellectual capital.

5. Financial methods to measure the intangible assets are based on a part of difference between market value and book value caused by emotions of investors.

\subsection{Models based on market capital}

This model calculates the value of intellectual capital based on the difference between market capitalization and equity capital and its different types are as follows:

1. Tobin $\mathrm{Q}$ model: is equal to division of market value to book value and if $q$ is greater than 1 , it indicates that the assets are worth more than their book value.

$I C=\mathrm{MV}+\left(\frac{M V}{q}\right)$

2. Intangible balance sheet model: is based on three components including the internal structure (organizational acquisition), the external structure, and individual competence.

3. Compare the market value and the Office model, based on the difference between the money that has been invested and cash flow from the sale of shares obtained in the present circumstances.

\subsection{Return on assets (ROA) models}

The average income of the organization before tax divided by average intellectual capital of the organization and its types are as follows:

Economic value added (EVA) model that emphasizes on maximizing the value of shareholder wealth.

Calculated intangible value model that is based on the net present value of average after-tax return surplus capital.

The value added intellectual coefficient (VAIC) model that measures the overall performance of value creation in the company.

\subsection{Balanced Scorecard models:}

In which there is possibility of creating composite indicators based on integrating intellectual capital components and include balanced Scorecard that emphasizes on learning and development, internal business processes, customer satisfaction and financial results.

1. Scandia navigator: based on this model intellectual capital will be recognizable by integrating a hidden structural capital and human capital together.

2. Monitoring of intangible assets: this model is based on three components including external structure, internal structure, and individual competencies.

3. Intellectual capital indicators model: that emphasizes on the integration of individual indicators in the form of an indicator, and linking changes in intellectual capital to market changes.

4. Intellectual capital measurement and accounting model: that is based on four components including human capital, organizational capital, market capital, and innovation investment.

\section{Objectives of Human Resources Accounting}

The main objective of the intellectual capital accounting is emphasis on managers to pay more attention to the maintenance of human resources and talents and intellectual capitals. Managers who do not think to create job satisfaction and positive incentives and do not care about job security, hope and loyalty, providing opportunities for development and human resources, cause the expulsion and resignation of staff. In order to achieve the following objectives, human resources accounting should be established in qualitative and quantitative terms.

- By recording the economic value of the intellectual capital in the organization's financial reports, and also taking into account the organization's investment in human resources, the human resource accounting shows impact of human resources on organizational performance. 
- Human resources accounting can help managers to increase the efficiency of human resource management and provide training and justified plans by management in evaluating various strategies.

- Human resource accounting can develop capital budgeting system, modify the quality of the return on investment and identify productivity and non-operationalized profit arising from investment in human resources.

- By calculating the value of human resources, the human resource accounting enables managers to make better use of scarce human resources.

\section{Methods of Human Resources Accounting Review}

Human resource accounting can be evaluated using two methods:

1. Human resources costing focused on cost parameters;

2. Human resources valuation focused on the direct relation of the value of human resources in obtaining business revenue for the organization.

\subsection{Human resources costing}

Human resources costing is composed of two parts:

1. The initial costs including all funds for supply and training of human resources, such as recruitment and selection, training, retraining and specialized and technical education;

2. Replacement or opportunity costs, including all costs to replace the previous human resources with new staff. Replacement costs consist of two parts: a) positional replacement costs such as the costs of providing education and training, retirement compensation costs and costs related to vacant positions; and b) other personnel costs, including bonuses and other privileges.

\subsection{Human resources valuation}

Intellectual capital accounting requires valuation of human resources rather than costing. Several researchers believe that humans is valuable like other resource since he/she is able to create future potential resources, while others reject this idea, and believe that humans are in fact beyond valuation.

Marcus has provided three answers to the question of why human resources should be valuated:

- Providing financial information in the form of financial terms that can be included in the financial reports in order to inform investors, employees, and creditors;

- Identifying the contribution of capital and labor in the overall performance of the organization;

- Quantifying the economic value of individuals for organizations to provide information for management and financial decisions.

- To measure human resources two steps should be passed: first, determining the value of human resources in non- monetary terms, and then representing it on the balance sheet in monetary terms.

\section{Non-monetary valuation of human resources}

Human Resource Accounting Committee has found the potential importance of non-monetary measures in the decision making process. So, one of these criteria can be preparing a list of important people of organizations and their skills as assets.

The most important non-monetary valuation variables include:

Causal variables: independent variables that are changed by the managers.

Intermediate variables: variables that have reflection on the health of the organization, such as loyalty, driving behavior, performance, objectives and understanding of the organization's members.

Final variables, such as production power, costs, growth and revenue and market share.

\section{The Monetary Methods of Human Resources Valuation}

Some applied methods of human resource valuation are as follows: 


\subsection{Economic value (current value)}

This theory is based on the capital value theory, i.e. market prices of assets include the discounted value of future benefits that will result from these assets.

\subsection{Replacement value theory}

The replacement value is costs of replacing human resources including costs of hiring new staff and their training costs, as well as transfer or turnover costs. In this method, in addition to the individual's position in the organization, the cost of transfer or fire of staff for poor performance is also considered.

\subsection{Value coefficient theory}

According to this theory, human resource value is equal to the difference between the total value of the company and the value recorded in the books of the company. In this method, an optional coefficient of zero to 2.5 is considered and employees are divided into four main categories of higher-level management, management, administrators, and staff. Costs created for staff in a period is considered in coefficients, and result of changes in the value of human resources during the period is shown.

\subsection{Auction theory}

According to this theory, firm is divided into investment centers, and services of specialized human resource is auctioned based on their jobs in investment facilities. To access scarce human resources, managers bid against each other.

\subsection{Theory of historical end cost}

This theory is based on the common principles of accounting. According to this theory, costs incurred for employees directly increase the value of their services. Historical end cost of human resources includes the cost of hiring and training that enhance the value human resources. This method results Due to its harmony with generally accepted accounting principles as a measure of assets, as well as its objectivity, this method is more likely than other methods to be accepted by the tax offices.

\subsection{State benefits assessment model}

This theory is one of the first and most fundamental models in the field of human resources value measurement applied by some organizations and associations, including the National CPAs. State benefits assessment model was presented in 1996 by Holtz. He examined value of an individual for an organization from two perspectives:

1. Expected conditional value of the individual: it is the potential value that is expected to be obtained by the organization if an individual continues membership of organization during the useful working lifetime.

The method of calculating the expected conditional value of the:

$\sum(C V)=\sum_{t=1}^{n}\left[\frac{\sum_{i=1}^{m-1} R i . \mathrm{P}(\mathrm{Ri})}{(1+r)^{t}}\right]$

CV: conditional value;

i: position of service $(1,2,3, \ldots, \mathrm{m})$;

Ri: value of the position of service;

$\mathrm{Rm}$ : value of the position of exit;

m: position of exit;

$r$ : discount rate;

t: expected tenures $(1,2,3, \ldots, n)$;

$\mathrm{P}(\mathrm{Ri})$ : The probability of obtaining interests associated with the position of services by the organization.

$\sum(R V)=\sum_{t=1}^{n}\left[\frac{\sum_{i=1}^{m} R i . \mathrm{P}(\mathrm{Ri})}{(1+r)^{t}}\right]$

$\mathrm{RV}$ : retrievable value. 


\section{Human Resources Reporting}

The main reasons for the assessment and reporting of human resources include:

- Further efforts for transparency of information in order to inform the external people of internal information;

- Providing a basis based on economic incentives for managing the organization and provision of extensive information to perform employee tasks;

- Trying to avoid under-reporting of assets;

- Determining the contribution of capital and labor in the overall performance of the organization;

- Determining whether the Human Resources of the organization has been maintained, reduced, or developed;

- Disclosure of information about investment that leads to better investing decisions. follows:

Conventional methods to reflect investments in human resources at the company's annual financial reports are as

The Board reports to the General Assembly of Shareholders:

These reports often include information on expenses related to human resources which may be significant or even more important than the actual expenses that have been made for assets. In addition, the board report should include information on the trends and costs of employee turnover.

Report in intangible assets:

In this method, major sums spent on intangible assets such as human resources are reported separately in the financial statements. The report should reflect expenditures made to a variety of intangible assets in the current period and in past periods.

Report in non-audited financial statements:

In this method, companies are able to present a set of financial statements as supplementary information to provide annual financial statements which include investments in human assets according to the proposed human resources accounting method. The report will stipulate that these financial statements are examined separated from financial statements prepared and presented in accordance with generally accepted accounting principles.

Report as contingent liabilities in the financial statements:

A contingent liability is an estimate of the amount and probability of liabilities and makes it possible to calculate the expected loss. In the contingent liabilities method, the relevant costs and liabilities are recognized only in case of probable under-representation of financial situation. If contingent liabilities are presented in the form of additional Notes, balance sheet and profit and loss adjustments will not be necessary.

Report in basic financial statements:

In this method, investment in human assets is considered as long-term assets and is amortized at the time of its expected useful lifetime. Some institutions and companies where manpower makes up the bulk of their investment apply this method, such as professional sports clubs.

\section{The Challenges Facing the Human Resources (Intellectual Capital) Accounting}

Pros of modern management divide production factors into four components of human, materials, machines and money. Human resources are only the number of people involved in the organization, but a combination of knowledge, skills, creative abilities, aptitudes, and attitudes of the workforce of an organization. In fact, the sum of innate abilities, acquired knowledge and skills of employees is referred to as human resources. Human resource costs can easily be reflected in the profit and loss statements. However, the main problem is to find a simple formula for accountants to valuate human resources. There is no generally accepted principle for the valuation of human resources. However, some companies in the world have made major efforts valuate their employees. In this respect, some problems of human resource accounting to be reflected in the financial statements are as follows:

Which expenditures should be considered as investment in capital assets?

Determining the expenditures as current or capital is related to their potential future services. So, the expenses are considered as expenditures in the period of benefits acquired, and if the benefits were related to future periods, should be expenditures be considered as assets.

How the expenditures of capital assets are depreciated?

The aim of human asset depreciation is compliance of costs with the benefits of their use. The organization can use group depreciation method for the employees of the organization and individual depreciation for managers.

How these assets can be removed from the accounts? 
When significant changes occur in the lifetime of people service, the human assets shall be adjusted like other asset and the remained non-depreciated assets should be regarded as loss for the period that the change has occurred.

How investments in human assets should be reported in financial statements?

People are almost free to leave the organization. Therefore, there is uncertainty about anticipating potential lifetime of human resource services. This problem can be resolved by taking into account a reservoir for expected costs of turnover.

Is human resource accounting a challenge or an opportunity?

Given that one of the objectives of human resource accounting is to improve the effectiveness of human resource management and to create opportunities for staff valuation policy, human resources are only highlighted in knowledgebased economy, where manufacturing industries are gradually converted into service industries and knowledge and skills are significant. A knowledge-based economy has knowledge-based companies and industries. In addition, since human resources are not assets in per se but their services are, the question is whether human or their services should be regarded as assets?

Components of human resources accounting believe that there are two main reasons for considering human resources as assets in the financial statements. One, current and potential investors need such information in order to valuate the performance of the company's financial situation. Moreover, investments in human resources are consistent with rules and regulations of considering human resources as assets. Therefore, the development of sciences and specialized jobs has made the role of capable human resource as a valuable asset undeniable. However, accounting has not still been able to properly valuate these valuable assets and reflect them in the financial statements for beneficiaries decision-makings, but has always considered it as a challenge.

\section{Conclusion}

Today, the situation is marked in such a way that no company has secure margins in its home and if a company is seeking survival, it should be thinking of expanding its business. What makes the organizations distinct and brings sustainable competitive advantage for them is fundamental attention to human resources and intellectual capital as the most valuable assets of the organization. Intellectual capital is very important in enhancing revenue, performance, efficiency and profitability of the organizations. Although generally accepted accounting standards prevent intellectual capital to be reflected in the financial statements, investors have understood the value of intellectual capital in their decisions and consider it essential for better performance and increased efficiency of companies and organizations. And today, despite the growing importance of intangible assets and especially the intellectual and spiritual capital in companies, most accounting systems are not able to calculate the performance of the company's intellectual capital based on a transparent and appropriate manner. However, through costing and valuation of human resources, human resources accounting can provide the information needed for human resource management and indicate whether human resources of organization has been maintained, reduced, or developed. Therefore, it can be said that there is a positive relationship between the organization's intellectual capital and organizational performance. Due to its role in assessing the costs, valuation of human resources and helping managers to make the correct decision, fundamental attention to human resource accounting is necessary.

\section{Recommendations}

In conclusion, recommendations are proposed in order to maintain and measure intellectual capital and operationalize and establish human resources in accounting system:

1. It is required that workplaces become universities where the entire staff whether new or old staff are constantly learning and teaching.

2. It must be institutionalized in organizations that knowledge exchange creates power and increases the validity and value of every person in the chain of information exchange.

3. Works should be based on knowledge and communities should be established based on knowledge.

4. The human resources development strategy and analysis of impact of human capital financial information on managers decision making should be prepared.

5. Managers should be informed of the benefits of deploying human resources accounting systems with an emphasis on the fact that investment in human resources are not costs and should be reflected in the balance sheet as other assets.

6. The relationship between intellectual capital and organizational performance should be conducted using data 
envelopment analysis.

7. Intellectual capital modeling and forecasting for future years with econometric methods is essential to inform investors of future performance of organizations.

\section{References}

Asadi, G.H., Alam Tabriz, A., and Rezaei A.S (2013) The impact of intellectual capital on economic value added, Journal of Accounting and Auditing, Accounting Association of Iran, no. 20.

Samadi, A. and Nasiri, H. (2010) Assessment of barriers to the development of human resources accounting in companies listed on the exchange, CPAs, no. 11, Tehran, pp. 41-54.

Momeni Farahani, F. (2009) Identifying, attracting and recruiting talented individuals, by Professor Graeme Kongton Seminar, Talent Challenges.

Abbasi, M. (2011) The effect of implementing human resources accounting systems in decision-making of managers and employee behavior," Journal of Management and Human Resources in the Petroleum Industry, No. 14, Tehran, pp. 117-44.

Momeni, A.R., Hemmati, A. and Moradi, H. (2012) Identifying and prioritizing barriers of establishing human resources accounting systems in organizations, Kar va Jame'eh Journal, Tehran, №. 142, pp 58-66.

Namazi, M. (2012) The Role of human resources accounting in knowledge management, Conference on Knowledge Management with Wealth creation Approach, Shiraz.

Shahly Zadeh, R, (2001) Costing, valuation and reporting of human resources.

Mirkamali, S.M. and Zohour Parvandeh, V. (2008) Intellectual capital management, necessity for organizations in knowledge-based era, Payam-e Modiriat, No. 28, 81-105.

Khavandkar, J. and Mottaghi, A. (2009) Intellectual capital, management, development, and evaluation models, Publications and Training Center of Industrial Research of Iran.

Talebnia, Gh. and Ghorbani, B. (2010) Examining the feasibility of using valuation models of human resources in audit firms that are member of Society of Iranian Credited Accountant Society, Accounting and Auditing Research, No. 6.

Yavarikhou, H. (2005) "Evaluation of the application of human resource accounting in the decision-making at electricity industry, Journal of Electricity Accounting, No. 44.

Santanu Ghosh and Amitava Mondal. (2009). "Indian software and pharmaceutical sector IC and financial performance".

Bontis, N., (2008), "Managing organizational Knowledge by diagnosing Intellectual capital: framing and advancing the state of the field", Journal of Management Reviews, Vol. 25, No. 1, PP. 41-60.

Jui-Chi Wang, (2008)"Investigating market value and intellectual capital for S\&P 500" , Journal of Intellectual Capital, Vol. 9 No. 4, ,

Brooking A., (2010), "Management of intellectual capital long range planning", Journal of Intellectual Capital, Vol. 30, No. 35, PP. 364365 .

Meng-Yuh Cheng, Jer-Yan Lin, Thomas W. Lin, (2008) "Censoring model for evaluating intellectual capital value drivers", Vol. 9 No. 4, pp. 639-654

Enzo Dia , Fabrizio (2009)"Aggregate Investment, Tobin's q and External Finance" CasalinNewcastle University Business School, NE1 7RU, Newcastle upon Tyne, UK.

Bontis, N., Keow, W. and Richardson, S., (2006), "Intellectual capital and business performance in Malaysian industries", Journal of Intellectual Capital, Vol. 1, No. 15, PP. 85-100.

Edvinsson, L. and Malone, M., (2009), Intellectual Capital: Realizing Your Company's True Value by finding its Hidden Brain Power, Harper Collins Publisher Inc., New York, NY.

Marques,E;(1976,Human Resource Accounting, Some Question and Reflections, Accounting Organization and Society, P.P 80-175.

Verma,Sh.\& Deve. Ph,2004,Measuring The Value of Human Resource Accounting \& Business Journal,P.P 46-48.

Kin Hang Chan, (2009), "An empirical study of companies in the Hang Seng Index, Impact of intellectual capital organisational performance", Vol. 16 No. 1, pp. 4-21 